\title{
Wirtualna edukacja w Polsce i na świecie
}

\section{E-learning in Poland and around the world}

\author{
Pawet Korcz ${ }^{1}$, Marek Matulewski ${ }^{2}$ \\ ${ }^{1}$ Pracownia Legilingwistyki, Instytut Językoznawstwa, \\ Uniwersytet im. Adama Mickiewicza \\ ul. Międzychodzka 5, 60-371 Poznań \\ pawel.korcz@gmail.com \\ ${ }^{2}$ Katedra Podstaw Logistyki, Wyższa Szkoła Logistyki \\ ul. E. Estkowskiego 6, 61-755 Poznań \\ marek.matulewski@gmail.com
}

\begin{abstract}
The paper deals with distance learning via IT systems. The authors presented types and models of e-learning. Next, the tools designed for creating and using the e-learning sources are described. Moreover, the offer of distance-learning courses on offer by Polish and worldwide universities is reviewed. The authors describe the operation mechanisms applied by universities and specializations offered by them. Finally, a short comparative characteristics of traditional teaching and e-learning is given. In conclusion the advantages and disadvantages of distant learning are discussed.
\end{abstract}

\section{Wstęp}

Jesteśmy świadkami rewolucyjnych zmian technologicznych. Postęp opanował niemal każdą dziedzinę życia człowieka, od wykonywania prostych czynności po loty w kosmos.

Dzięki wykorzystaniu transmisji satelitarnych, łączy światłowodowych, bezprzewodowych sieci, nośników danych o dużych pojemnościach, człowiek stał się mobilny. W każdym miejscu i o każdej porze, dzięki nowoczesnej technologii ma on dostęp do informacji. Ta technologiczna rewolucja, której jesteśmy świadkami zmieniła nasze codzienne życie. Wiele firm rezygnuje z utrzymywania wielkich siedzib, wychodząc z założenia, że pracownik, którego terminal jest podłączony do Internetu, w dowolnym miejscu może wykonać tę samą pracę efektywniej i z niższym nakładem finansowym.

Podobnie sytuacja wygląda $\mathrm{z}$ edukacją. Dlaczego student musi w wyznaczonym czasie i miejscu uczestniczyć w wykładach? Czyż nie byłoby łatwiej i bardziej efektywnie, żeby żak, zamiast wstawać $\mathrm{w}$ pośpiechu wczesnym rankiem w mroźny dzień wypoczęty usiadł wygodnie w swoim fotelu przed komputerem, połączył się ze swoją uczelnią i w indywidualnym, dopasowanym do swoich potrzeb tempie odbył wykłady i ćwiczenia, a nawet 
egzamin zdawał bezstresowo w domowym zaciszu? Otóż student może to zrobić w każdej chwili zapisując się na jeden $\mathrm{z}$ wielu, działających na całym świecie, wirtualnych uniwersytetów.

\section{Rodzaje e-learningu}

Naukę na e-uczelniach można pobierać w następujących konfiguracjach: synchronicznej, asynchronicznej indywidualnej oraz w trybie mieszanym, a także w trybie indywidualnym.

\subsection{Nauczanie synchroniczne}

Pierwszy $\mathrm{z}$ nich to e-learning $\mathrm{w}$ trybie „czasu rzeczywistego”. Przypomina on najbardziej klasyczną metodę nauczania tę, którą znamy ze szkół czy ze studiów. W jednym czasie, za pomocą aplikacji uruchomionej $\mathrm{w}$ przeglądarce internetowej spotykają się studenci i wykładowca. Podczas wykładu korzysta się z takich technik jak transmisja głosowa, a nawet, jeśli pozwala na to łącze, transmisja video. Aplikacja umożliwia pisanie po wirtualnej tablicy oraz udostępnia czaty, przez które można wymieniać informacje. Takie zajęcia prowadzone są pod kontrolą wykładowcy. Nauka w takim trybie pozwala na swobodną wymianę informacji zarówno pomiędzy słuchaczami jak i osobą prowadzącą.

Niewątpliwą korzyścią nauczania synchronicznego jest bezpośredni kontakt nauczyciela ze studentami, a głównym minusem takiej metody jest praca w wyznaczonym czasie. Problem stanowi również nauczanie ludzi mieszkających w różnych strefach czasowych.

\subsection{Nauczanie asynchroniczne}

Główną zaletą metody asynchronicznej jest to, iż naukę można pobierać w dowolnym czasie. Jest to idealne rozwiązanie dla ludzi pracujących w rożnych godzinach czy też studiujących więcej niż jeden kierunek.

Student takiej uczelni za pomocą przeglądarki internetowej loguje się do systemu uczelnianego, tam rozpoznany przez system autoryzacji jest dopuszczony do bazy danych, w której znajdują się wszystkie potrzebne informacje dotyczące słuchacza. Baza danych zawiera wiadomości na temat zdanych przedmiotów, rozpoczętych oraz dostępnych kursów itp. Egzaminy w takim systemie zdaje się głównie przez rozwiązywanie elektronicznych testów, aczkolwiek zdarza się, że uczelnie organizują jeden, bądź więcej zjazdów na uczelni w czasie sesji. Uczestnik takiego trybu ma dostęp do poczty elektronicznej, za pomocą której ma kontakt z wykładowcami oraz innymi słuchaczami, a także do narzędzi w postaci czatów oraz forum dyskusyjnego, za pomocą których może wymieniać poglądy z innymi uczestnikami kursu.

Taka metoda nauki jest skierowana dla ludzi zdyscyplinowanych, którzy częściowo sami pokierują swoją edukacją. Bezpośredni brak kontaktu z wykładowcą może stanowić pewien problem, ale zawsze można skonsultować się z nim za pomocą poczty elektronicznej lub z innymi słuchaczami na czacie czy na grupie dyskusyjnej.

\subsection{Nauczanie w trybie mieszanym}

Kształcenie w trybie mieszanym ocenia się jako bardzo efektywne i cieszy się ono coraz większą popularnością. Również eksperci akademiccy uważają ten tryb za najbardziej skuteczny. Jest on stosowany $\mathrm{z}$ powodzeniem między innymi w Szkole Głównej Handlowej oraz na Politechnice Gdańskiej. W obu przypadkach wykłady prowadzone są w sposób stacjonarny, uzupełniane zajęciami wirtualnymi poprzez internetowy system zarządzania e-learningiem. System ten obejmuje dwie strefy związane z procesem nauczania: zarządzanie treścią oraz zarządzanie nauczaniem. W praktyce zadania te są wykonywane przez dwa niezależne systemy. Pierwszy to LCMS (ang. Learning Content Managment System - system zarządzania treścią nauczania) i drugi LMS (ang. Learning Managment System - system zarządzania procesem nauczania). Niektórzy producenci oprogramowania zarządzającego nauczaniem integrują obie funkcje w jednej platformie zarządzającej e-learningiem.

\subsection{Nauka indywidualna}

Innym modelem e-learningu jest tryb indywidualny. Jest on jednak metodą nauki nie wykorzystywaną w szkolnictwie wyższym, a dużą popularnością cieszy się wśród organizatorów 
różnych kursów zwłaszcza wewnątrz firmowych, takich jak np.: szkolenie $\mathrm{z}$ wiedzy o oprogramowaniu Microsoft, Oracle, czy też sprzętu Cisco. Taki rodzaj nauki jest również dobrą metodą przygotowania do egzaminu.

Tryb ten stosowany jest także przez firmy uczące języków obcych. Narzędzia wykorzystywane w tym rodzaju e-learningu są takie same jak w trybie asynchronicznym $\mathrm{z}$ tą różnicą, że kursant sam decyduje o tematyce jak i czasie szkolenia.

\section{Modele ksztalcenia}

Model kształcenia jest zawsze oparty na przyjętej wcześniej strategii. To ona wprowadza ogólne założenia przekazywane następnie przez prowadzącego, wytycza kierunek nauki i nadaje ogólny ton każdemu z kursów. Strategia nauczania zawiera metody, narzędzia, plany oraz techniki ułatwiające naukę. W edukacji online stosuje się kilka modeli kształcenia.

\subsection{Model ACCEL}

Model ACCEL (Active, Collaborative, Customized and Accessible, Excelent Quality, Lifestyle fitted) to model który opiera się na interaktywnym zdobywaniu wiedzy. Studenci uczestniczą $\mathrm{w}$ aktywnych formach nauki, współpracują i wymieniają między sobą doświadczenie. Kurs jest dostosowany do poziomu wiedzy uczestników i uwzględnione są w nim potrzeby oraz wymagania studentów. W modelu tym uwzględnia się również takie czynniki jak uwarunkowania czasowe, techniki nauki, poziom opanowania materiału. Kurs jest zaprojektowany tak, aby student skupiał się jedynie na nauce, osiągając wyznaczone cele. Model ACCEL ma wbudowane mechanizmy łączności pomiędzy studentami oraz nauczycielem. Nauka przy zastosowaniu takiego modelu zapewnia również dostęp do wysokiej jakości materiałów oraz do elektronicznych bibliotek udostępniających literaturę z zakresu prowadzonego szkolenia. Model ten charakteryzuje się niewielkimi kosztami uczestnictwa i jest dopasowywany czasowo do uczestników.

\subsection{Model ACTIONS}

Model ACTIONS (Access, Costs, Teaching and Learning, Interactivity and User-friendliness, Organizational Issues, Novelty, Speed) stosuje się przy tworzeniu kursu multimedialnego na stronie www.

Przy realizacji projektu według wytycznych modelu ACTIONS bierze się pod uwagę następujące czynniki (Wirtualna Edukacja Nr 13):

$>$ Czy studenci mają dostęp do właściwej technologii?

$>$ Jaka jest struktura kosztów tej technologii?

$>$ Jakie modele edukacyjne są wymagane, aby osiągnąć wyznaczone cele kształcenia?

$>$ Jaki wprowadzić model interaktywności i czy jest on łatwy w użyciu?

$>$ Jakie są organizacyjne wymagania i jakie bariery trzeba pokonać, aby osiągnąć sukces?

$>$ Jaka nowoczesna technologia jest zastosowana?

$>$ Jak często kurs jest modyfikowany, oraz jak szybko i w jaki sposób otrzymuje się materiały?

\subsection{Modele klasy wirtualnej}

Do najczęściej stosowanych modeli klasy wirtualnej należą następujące systemy: ICARE, APT oraz LADR.

\subsubsection{Model ICARE}

Model ICARE (Introduction, Connect, Apply, Reflect, Extend) został stworzony przez San Diego State University Tools, Templates and Training ITI Workshop. Jest to system, który cechuje się uporządkowaną strukturą każdego modułu kursu. Model ten składa się z wprowadzenia, streszczenia oraz z przedstawienia celów do osiągnięcia.

$\mathrm{W}$ celu stworzenia modułu korzystamy $\mathrm{z}$ wbudowanych narzędzi, które umożliwiają nam następujące funkcje (Wirtualna Edukacja $\mathrm{nr}$ 13):

$>$ wprowadzenie do modułu i zapoznanie z jego zawartością oraz z celami jakie należy osiągnąć;

$>$ połączenie z nowymi informacjami i koncepcjami;

$>$ pokazanie studentom jak mogą wykorzystać nowe informacje;

$>$ refleksji dotyczącej nabytej wiedzy;

$>$ rozszerzenia swojej aktywności i jej ewaluację. 


\subsubsection{Model APT}

Model APT (Analyze, Practice, Talk) składa się z trzech podstawowych segmentów, potrzebnych od osiagnnięcia celu wyznaczonego $\mathrm{w}$ nauczaniu. Pierwszy $\mathrm{z}$ nich to analiza nowego materiału.

Drugim jest nabywanie praktyki $\mathrm{w}$ oparciu o poznany materiał. Trzeci etap to dyskusja z innymi uczestnikami kursu na poznane tematy. Model APT jest używany między innymi w Educational Technology 541 course w San Diego State University.

\subsubsection{Model LADR}

Model LADR (Lecture, Application, Discussion, Reflection) składa się z czterech segmentów. Pierwszy z nich polega na wprowadzeniu do systemu nowego materiału. Następnie studenci muszą wykonać aplikację używając do tego celu poznany materiał. Trzeci segment to wymiana poglądów pomiędzy uczestnikami kursu oraz rozmowa na temat zdobytych doświadczeń. Ostatni to podsumowanie dotyczące zdobytej wiedzy.

\section{Narzędzia do tworzenia e-learningu}

Do prowadzenia kształcenia na odległość wiele firm przygotowało odpowiednie oprogramowanie. Są to systemy komercyjne, ciągle rozwijane, mające już wieloletnią historię. Wywodzą się i są stosowane $\mathrm{w}$ większości na uniwersytetach amerykańskich, dlatego właśnie ich specyfika i technologia wykonania przystosowana jest do warunków panujących w tym kraju. Są to platformy programowe skalowane, a co za tym idzie bardzo uniwersalne i pomysłowe, wykorzystujące niemalże wszystkie dobrodziejstwa sieci Internet. Dostarczają one szereg narzędzi do nauki, współpracy, zarządzania kursami (przedmiotami) i administrowania całym systemem. To właśnie te narzędzia sprawiają, że nie zniechęcamy się do korzystania z kursu, czy studiów na odległość. To ich ciągły rozwój, wykorzystywanie nowych technologii sprawiło, że tak wiele osób na świecie, a także w Polsce wybiera ten sposób nauki.

\subsection{Courseinfo - Blackboard}

Narzędzie to jest klasycznym systemem służącym do zarządzania kursami, opartymi na tzw. szablonach. Narzędzie dostępne jest zarówno na platformie Unixowej jak i Windows, przy czym platformy unixowe są rekomendowane przez producenta. Produkt nie zawiera dobrych narzędzi pozwalających na tworzenie kursów, lecz nastawiony jest na import lekcji utworzonych za pomocą narzędzi niezależnych. Niewątpliwą zaletą jest fakt, że tworzenie kursów jest proste i nie wymaga znajomości nawet HTML. Początkowe wersje tego produktu nie były stuprocentowo stabilne. Technologia zawodziła zwłaszcza w przypadku uczestnictwa większej liczby studentów. Nowe wersje, w tym przeznaczony na rynek korporacji Courseinfo Enterprise, nie posiadają już tych wad. Poza funkcjami telekonferencji i wideo konferencji posiada wszystkie możliwe narzędzia nauczania synchronicznego - zarówno komunikację $\mathrm{w}$ trybie tekstowym (chat) jak też komunikację głosową poprzez mikrofon i głos przenoszony po łączach internetowych. Podobnie jak inne omawiane produkty z tej grupy Courseinfo posiada możliwość współdzielenia aplikacji pozwalającą na przejęcie przez prowadzącego kurs kontroli nad ekranem - konieczne na przykład do wskazania studentowi istotnych elementów pomocnych do rozwiązania problemu. Jedynie to narzędzie oraz LearningSpace posiadają funkcję „przeglądarki grupowej”.

\subsection{Topclass - WBT}

Topclass na tle prezentowanych narzędzi dysponuje dość prostą funkcjonalnością, która jednakże w wielu zastosowaniach może być wystarczająca. Producent oprogramowania, firma WBT jest wspólnym Amerykańsko-Irlandzkim przedsięwzięciem. Podobnie jak większość prezentowanych tu rozwiązań historia Topclass sięga korzeniami prac akademickich nad uczeniem na odległość. Mechanizm komunikacji w Topclass ogranicza się do poczty elektronicznej, listy dyskusyjnej oraz mechanizmu class announcements pozwalającego na komunikację nauczyciela lub administratora systemu do wszystkich uczestników i informowanie ich o nowych kursach, o teście lub komunikując inne istotne dla życia wirtualnej klasy wydarzenia. 


\subsection{WebCT - Universal Learning Technology}

Stworzony przez Uniwersytet Kolumbii Brytyjskiej WebCT początkowo jako grant dla potrzeb edukacyjnych uczelni, a od 1997 roku oferowany także komercyjnie, należy do relatywnie tanich rozwiązań. Oparty jest na narzędziach do tworzenia i zarządzania kursami oraz skryptami CGI scalającymi te elementy. W maju 1999 roku produkt został zakupiony przez Universal Learning Technology, posiadający już wcześniej narzędzie DL pod nazwą Bravo. Po zalogowaniu się użytkownika do systemu widzi on ekran z wejściem do sześciu opcji, z których najważniejsze to:

$>$ Course Information - zawierający informacje o przewidzianym na dziś kursie;

$>$ Communications - zawiera opcję komunikacji poprzez e-mail oraz chat;

$\mathrm{Na}$ górnej listwie ekranu znajduje się wejście do MyWebCT, skąd można się dostać do narzędzi administratora i twórcy kursu. Niewątpliwą wadą produktu w porównaniu do pozostałych rozwiązań jest mała ilość wbudowanych mechanizmów synchronicznych, na przykład brak funkcji porozumiewania się głosem.

WebCT ma podobne jak LearningSpace Lotusa wymagania sprzętowe. Dla systemu unix powinna być to jednostka z procesorem Pentium III, wyposażona w przynajmniej 256MB pamięci operacyjnej dla 15 tys. kont użytkowników oraz 512MB RAM przy ilości powyżej 15 tys. Wymagania te zwiększają się w przypadku systemu Windows. Przy mniejszej instalacji polecana jest maszyna 2 procesorowa i $512 \mathrm{MB}$, przy większej (powyżej 15 tys. kont) 1 GB RAM oraz maszyna wieloprocesorowa (quad).

Polityka cenowa zakłada roczną licencję na jednego użytkownika oraz opłatę za pomoc techniczną. W przypadku uczelni dla liczby studentów do 50 opłata za licencję wynosi 335 USD, wsparcie techniczne 135 USD. Firma Universal Learning Technology szczyci się posiadaniem 6,7 miliona studentów.

\subsection{LearningSpace - Lotus Notes}

LearningSpace jest jedynym z niewielu produktów z kategorii narzędzi Distance Learning, które są dostępne w sprzedaży bezpośrednio w Polsce. Z informacji udzielonych przez Lotus Development Polska, licencje na LearningSpace zakupiły już miedzy innymi takie uczelnie jak Politechnika Warszawska i Politechnika Wrocławska. Z oprogramowania tego korzysta także Computerland, partner Lotusa w Polsce. Na świecie LearningSpace jest wykorzystywany m. in. przez IBM. Obecna polityka cenowa zakłada sprzedaż licencji dla studentów, wykupywanych jednorazowo,

na dowolną ilość kursów. Oprogramowanie, którego architektura oparta została o javę, pozwala na naukę w trybie synchronicznym - tzw. wirtualna klasa oraz asynchronicznym. W rozwiązaniu zawarty jest nabyty w 1999 roku od Macromedia produkt Pathware, narzędzia administracyjne oraz Samertime pozwalający na kontakt w czasie rzeczywistym, bazujący na standardach audio i wideo H.323 oraz T.120. Moduł Core serwuje informacje potrzebne do samodzielnego uczenia się przez Internet. Moduł Collaboration zawiera narzędzia pozwalające na naukę w grupie i wspólną dyskusję. Użytkownik może korzystać z tych części niezależnie od siebie. Od czwartej wersji LearningSpace nie potrzeba już, w porównaniu do wersji wcześniejszych Serwera Domino, wymagana jest natomiast relacyjna baza danych. Może to być Oracle, DB2 lub SQL. Wszystkie pracują pod Windows Server a na Oraclu można pracować także pod Solarisem.

Interfejsem użytkownika jest przeglądarka, która powinna być podłączona do Internetu z minimalną prędkością $28,8 \mathrm{~Kb} / \mathrm{s}$ Server LearningSpace w wersji 4 wymaga minimum $256 \mathrm{MB}$ RAM zarówno na część Core jak i na część Collaboration. Obydwie części (serwery) mogą być umieszczone na jednej maszynie, wymaga ona jednak wtedy więcej niż 256 MB RAM (najlepiej co najmniej $512 \mathrm{MB}$ ) i dość wydajnego procesora (ewentualnie wielu procesorów).

\subsection{Total Knowledge Management - Generation 21}

Powstała w 1996 roku Generation 21 doczekała się do dziś 100 tysięcy użytkowników. W 1999 firma została przejęta przez Advantage Learning Systems. Rozwiązanie składa się z modułów: Development, Publisher, Management, Distance Learnig i Exteneded Distance Learning. 
Moduł Development służy do tworzenia obiektów (curriculum) i zapisywania ich w relacyjnej bazie danych. $\mathrm{Z}$ obiektów tych buduje się następnie kursy. Dzięki temu obiekty mogą być wielokrotnie używane $\mathrm{w}$ różnych kursach. Zmiany na poziomie obiektów pociągają automatyczne uaktualnienie $\mathrm{w}$ kursach, które te obiekty zawierają. Zgodnie $\mathrm{z}$ zapewnieniami producenta tworzenie kursów nie wymaga umiejętności programowania.

Moduł Publisher przygotowuje materiały pomocnicze do procesu nauki - podręczniki, materiały szkoleniowe w postaci stron internetowych, dokumentacji papierowej lub CD.

Moduł Distance Learning służy do połączenia terminal studenta $\mathrm{z}$ serwerem zawierającym kursu. Studenci mogą komunikować się pomiędzy sobą lub z osobą prowadzącą kurs poprzez e-mail, w trybie pogawędki (chat) lub poprzez forum dyskusyjne.

Moduł Extended Learning zawiera w sobie moduły Performance Support, Assessment, Library. Moduł Performance Support ułatwia przeszukiwanie przez uczącego się bazy danych w celu znalezienia odpowiedzi na zadawane przez program uczący pytanie. Moduł Assessment pozwala na zapoznanie się tworzących kurs z raportami dotyczącymi przebiegu uczenia zarówno poszczególnych studentów jak i grup studentów i służy głównie wykryciu braków w proponowanym programie szkoleniowym i optymalizacji kursu. Moduł Library to baza danych, którą użytkownik - student może przeszukiwać w zależności od przyznanego mu poziomu dostępu do danych.

Moduł Management pozwala na tworzenie połączeń pomiędzy bazą danych służącą do uczenia a innymi relacyjnymi bazami danych, do których można się dostać przez mechanizm ODBC, w celu transferu danych. Moduł zawiera także mechanizm rejestracji użytkowników sprzęgnięty z oprogramowaniem do pobierania płatności z użyciem kart kredytowych.

System pracuje z Windows oraz IIS 4.0. Wymagania sprzętowe to maszyna dwuprocesorowa $\mathrm{z}$ minimalną pamięcią 512MB RAM.

\subsection{Docent Enterprise - Docent}

Kalifornijska firma Docent współpracuje między innymi z HP (Hewlett Packard). Jej rozwiązanie składa się z następujących elementów:

$>$ Learning Management Server, służący do rejestracji, płatności, zarządzania kursem i sporządzania raportów;

$>$ Content Delivery Server, służący do dostarczania kursów;

$>$ Mobile, służący dostarczaniu kursów studentom do nauki w trybie offline, poza siecią;

$>$ Desktop, narzędzie służące do tworzenia i publikacji kursów. Składa się z modułów Outliner i Publisher;

Produkt kierowany jest do korporacji, zakłada współdziałanie z procesem sprzedaży korporacji i systemami CRM (Customer Relations Manangement). Kursy tworzone przy pomocy narzędzia składają się z części interaktywnych (sieciowych) oraz lekcji samodzielnych (na bazie nośnika CD lub ładowane $\mathrm{z}$ sieci na twardy dysk). Ambicją Docenta jest wspomaganie całego procesu szkolenia od przygotowania kursu poprzez jego dystrybucję aż po scertyfikowanie studenta i usługi posprzedażowe. Kursy przygotowywane są wstępnie w dowolnym edytorze HTML zintegrowanym z Outlinerem. Narzędzie to pozwala także na integrację z kursem obiektów multimedialnych audio, wideo a także Javy lub Java Skryptów. Zadaniem Outlinera jest przygotowanie zawartości kursu oraz testów. Docent Enterprise Server pracuje na jednym z systemów operacyjnych: Windows XP, Windows 2000, Windows NT lub Solaris 2.5+. Wymaga co najmniej 256MB RAM i serwera www Netscape 3.6+, Microsoft IIS, Apache lub innego wspierającego standard skryptów CGI. Jako baza danych może być użyty Oracle w wersji 7.3.3+ lub 8.0 oraz SQL w wersji 7.

\subsection{Meeting Point - CUseeMe}

Meeting Point wraz z jego rozszerzeniem ClassPoint pozwala na stworzenie wirtualnej klasy, w której komunikacja odbywa się w oparciu o mechanizm wideo-konferencji. Technika prowadzenia zajęć w ClassPoint umożliwia nauczycielowi wywołanie ucznia i przekazanie mu głosu (oraz obrazu) - tzw. spotlight, jak również pozwala na zgłoszenie się samodzielne studenta $\mathrm{w}$ celu zakomunikowania klasie istotnej informacji (podniesienie ręki). Oprócz głosu i obrazu działa także bardziej powszechny mechanizm pogawędki (chat) oraz 
przeglądarki grupowej (patrz - słownik). Oprogramowanie pozwala instruktorowi na oglądanie jednocześnie do 12-tu studentów (bez względu na to czy któryś z nich jest aktualnie „przy głosie”. Mechanizm wideo konferencji umożliwia prowadzącemu zadawanie pytań całej klasie, naprowadzanie na odpowiedź i w końcu sprawdzenie odpowiedzi udzielonych przez wszystkich dokładnie tak samo, a być może nawet z lepszą skutecznością niż w przypadku lekcji tradycyjnych. Produkt kierowany jest do trzech segmentów: instytucji prywatnych i rządowych, szkół średnich i uniwersytetów oraz do szkół podstawowych.

Meeting Point wspiera dwa standardy komunikacyjne: własny CuseeMe oraz H.323. W wymaganiach sprzętowych mniej restrykcyjny jest standard CuseeMe. Jako serwera HTTP można użyć IIS w wersji co najmniej 4 dla Windows NT / 2000/ XP lub Netscape Enterprise Server w wersji 3.6.2+, Apacha dla systemów opartych o Sun Solaris oraz Linux Red Hat. Wymagania sprzętowe na serwer to co najmniej Pentium IV (w przypadku rozwiązań opartych o Intela) lub Sun Enterprise 250 Ultra Sparc 2 (400 MHz ) w przypadku Sun'a. Wymagane jest, co najmniej 256 MB RAM. Dla mniej niż 25 użytkowników korzystających ze standardu H.323 wystarczy serwer jednoprocesorowy. W przypadku większych rozwiązań (do 50 użytkowników dla H.323) konieczne jest użycie maszyn 2 procesorowych.

\section{$4 \quad$ Rzeczywiste szkoły w wirtualnym świecie}

Najwięcej szkół wyższych oferujących naukę przez sieć znajduje się w Stanach Zjednoczonych, Anglii, Australii i krajach skandynawskich. Krajowa oferta jest również bogata. Do wyboru mamy wiele renomowanych uczelni, które wzbogaciły swoją ofertę o edukację on-line.

\subsection{Polskie uczelnie on-line}

\subsubsection{Wyższa szkoła Zarządzania}

Dość interesującą propozycję posiada Wyższa Szkoła Zarządzania. Swoją działalność on-line rozpoczęła w maju 2001 roku. Studenci korzystają z platformy e-edusystems a szkoła może się poszczycić nagrodą Teraz Polska, którą otrzymała za kształcenie na odległość.

Drogą elektroniczną mamy możliwość zdobycia dyplomu licencjata lub magistra z zakresu Zarządzania Biznesem. Czesne na tym kierunku za rok akademicki 2005/2006 wynosiło 225 PLN za miesiąc.

\subsubsection{Politechnika Koszalińska}

Bogatą ofertę e-learningową przedstawia Politechnika Koszalińska, która swoją działalność on-line prowadzi od roku akademickiego 2003/2004. Student zdobywa wiedzę za pomocą platformy e-learningowej, która łączy ze sobą zalety elektronicznych programów edukacyjnych z możliwością bezpośredniego kontaktu z nauczycielem. Politechnika Koszalińska oferuje nowoczesne specjalności kształcenia w tej formie studiów:

$>$ Inżynierskie Zastosowania Komputerów;

$>$ Inżynieria i Zarządzanie;

$>$ Logistyka Przemysłowa;

> Zarządzanie i Marketing Przemysłowy;

$>$ Eksploatacja i Marketing Pojazdów Samochodowych;

$>$ Inteligentne Systemy Wyposażenia i Ochrony Obiektów;

$>$ Nauczyciel Informatyki;

$>$ Techniki Komputerowe w Inżynierii Produkcji;

$>$ Inżynieria Żywności na kierunku Technika Rolnicza i Leśna.

> Więcej informacji o tej uczelni można zdobyć odwiedzając stronę http://www.studianet.pl/

\subsubsection{Zachodniopomorska szkoła biznesu}

Chcąc zdobyć wykształcenie ekonomiczne z zakresu informatyki warto zapoznać się z ofertą Zachodniopomorskiej Szkoły Biznesu. Jest to uczelnia, która od roku akademickiego 1999/2000 urozmaiciła swoją ofertę możliwością studiowania on-line. Edukację można prowadzić na studiach uzupełniających magisterskich ze specjalności Informatyka gospodarcza. Kierowanie 
tej specjalności powierzono Prof. Dr hab. Zenonowi Binkowi, który wcześniej prowadził eksperyment z nauczania na odległość z Zarządzania Informacją.

Zdobywając dyplom $\mathrm{z}$ tego kierunku absolwent posiada wiedzę teoretyczną oraz umiejętności praktyczne $z$ analizy oraz projektowania systemów informatycznych wspomagających zarządzanie. Duży nakład postawiony jest na zapoznanie studenta z SQLowymi bazami danych.

Kierunek ten przeznaczony jest głównie dla osób które posiadają dyplom licencjacki z ekonomii lub inżyniera z informatyki, a chcą zdobyć tytuł magistra ekonomii. Dokładna oferta tej uczelni znajduje się na stronie http://www.zpsb.szczecin.pl.

\subsubsection{Polsko - Amerykańskie Centrum Zarządzania w Lodzi}

Bardzo ciekawą propozycję nauki na odległość z technicznego aspektu wykorzystywanych technologii posiada Polsko-Amerykańskie Centrum Zarządzania w Łodzi (PAM Center). Do edukacji wykorzystuje się zaawansowane technologie teleinformatyczne takie jak: Oracle eLearning, WebCT, RealVideo, pocztę głosową, sprzęt widokonferenyjny firmy PictureTel.

Centrum powstało w 1995 roku w ramach programu PAM Center. Swoją wiedzę menadżerską można wzbogacić uczestnicząc w studiach Global Mini MBA. Są to studia realizowane wspólnie przez Wydział Zarządzania Uniwersytetu Łódzkiego i The Robert H. Smith School of Business Uniwersytetu Maryland (USA). Program ten, oparty na powszechnie uznanym standardzie amerykańskim, został stworzony $\mathrm{w}$ celu kształcenia nowoczesnej kadry menedżerskiej, przygotowanej do pełnienia funkcji kierowniczych w warunkach szybko zmieniającego się otoczenia i zaostrzającej się konkurencji.

Program obejmuje dziedziny zarządzania, takich jak: Rachunkowość Finansową i Zarządczą, Makroekonomię, Zarządzanie Finansowe, Marketing, Zarządzanie Zasobami Ludzkimi, Logistykę, Zarządzanie Systemami Informatycznymi i Zarządzanie Strategiczne. Integralną częścią programu jest realizacja Grupowego Projektu Doradczego na zamówienie konkretnego przedsiębiorstwa i udział w Case Competition. Stosowane są aktywne metody kształcenia, m.in. projekty grupowe połączone z prezentacjami multimedialnymi, analizy studiów przypadków i gry symulacyjne.

PAM Center jest organizatorem Studium Podyplomowego Podstaw Nauczania na Odległość. Jest to unikalny $\mathrm{w}$ Polsce program kształcący nauczycieli, organizatorów i administratorów edukacji, którzy w swojej pracy zamierzają korzystać z nowych metod dydaktycznych. Studium jest projektem realizowanym wspólnie przez Wydział Nauk o Wychowaniu UŁ i PAM Center. Program Studiów nawiązuje do doświadczeń University of Maryland i Prince George's Community College (USA), a także kilkuletnich doświadczeń PAM Center w stosowaniu metody nauczania na odległość.

\subsubsection{Politechnika Warszawska}

Chcąc zdobywać wiedzę za pomocą e-learningu warto zapoznać się z ofertą Politechniki Warszawskiej. Działa tam prężnie od kwietnia 2001 roku Ośrodek Kształcenia na Odległość. Dzięki współpracy sześciu wydziałów Politechniki Warszawskiej oferuje on bogatą gamę produktów edukacyjnych. Oferta składa się z:

$>$ Zaocznych Studiów Inżynierskich na Odległość, studia czteroletnie w formule SPRINT, prowadzone od roku akademickiego 2001/02 przez trzy Wydziały: Elektroniki i Technik Informacyjnych, Elektryczny i Mechatroniki;

$>$ Studia Podyplomowe Informatyka i techniki Internetu, dwu- i trzysemestralne, prowadzone przy Wydziale Elektrycznym od roku akademickiego 2002/03;

> Studia Podyplomowe "Narzędzia i techniki wirtualnej edukacji", dwu- i trzysemestralne, prowadzone przy Wydziale Elektroniki i Technik Informacyjnych, od roku akademickiego 2004/05;

$>$ Zaoczne Uzupełniające Studia Magisterskie na Odległość, studia dwuletnie w formule SPRINT, które zostały wprowadzone w roku akademickim 2005/06 przez dwa Wydziały: Elektroniki i Technik Informacyjnych i Elektryczny, przy udziale pracowników innych Wydziałów Uczelni (Ośrodek Kształcenia na Odległość przy Politechnice Warszawskiej).

Ośrodek posiada również ciekawą ofertę dla studentów, którzy chcą wzbogacić swoją wiedzę z konkretnego przedmiotu lub grupy przedmiotów. Istnieje możliwość podjęcia nauki w trybie określanym przez Politechnikę Warszawską ,student krótkoterminowy”. 
Studenci studiów dziennych politechniki mogą bezpłatnie studiować Przedmioty Informatyki w ramach przedmiotów obieralnych na danym Wydziale za zgodą Dziekana. Ośrodek Kształcenia na Odległość od pierwszego stycznia 2005 roku uczestniczy w programie REVE (Real Virtual Erasmus). Jedną z ważniejszych idei tego programu jest rozpowszechnienie wymiany wirtualnych studentów między uczelniami kształcącymi na odległość. W ramach programu organizowane są kursy i wykłady na uniwersytetach partnerskich. Politechnika Warszawska w ramach programu REVE uruchomiła kurs Microvawe Transistor Power Amplifirers (szczegóły na stronie http://www.okno.pw.edu.pl/OKNO/doktorant/index1.htm).

\subsubsection{Szkoła Główna Handlowa w Warszawie}

W Szkole Głównej Handlowej w Warszawie na studiach zaocznych stosowany jest system mieszany. Oprócz studiów stacjonarnych wdrożony jest system e-learning, który umożliwia:

$>$ prezentację materiałów uzupełniających do wykładów i ćwiczeń na studiach dziennych, zaocznych, doktoranckich i podyplomowych. Nauczyciel może uzupełnić zajęcia stacjonarne o dodatkowe treści, zadania, testy i ćwiczenia lub także rozbudować program wykładu (ćwiczeń) o całkiem nowe zagadnienia. Wykładowca może również zamieścić $\mathrm{w}$ systemie materiały prezentowane na foliach w czasie wykładu, co pozwala usystematyzować zdobytą przez studenta wiedzę.;

$>$ prowadzenie pełnych wykładów na studiach dziennych, zaocznych i podyplomowych, rozbudowujących ofertę programową uczelni;

$>\quad$ organizację i prowadzenie kursów i szkoleń także dla odbiorców spoza SGH.

System e-sgh.pl znakomicie sprawdza się jako platforma wspomagająca nauczanie na studiach zaocznych w SGH. Wielu wykładowców oferuje swoim studentom materiały uzupełniające. Są to materiały systematyzujące nabytą w czasie zajęć wiedzę lub też rozbudowujące program kształcenia. Materiały te można podzielić na materiały statyczne oraz zestawy, często interaktywnych zadań, testów i ćwiczeń. W pierwszym przypadku student jedynie zapoznaje się z prezentowanymi treściami oraz dyskutuje $\mathrm{z}$ nauczycielem na forum dyskusyjnym i czacie. W drugim przypadku, student oprócz czytania (lub odsłuchiwania) materiałów, zobligowany jest do rozwiązywania zadań i testów. Wyniki i rozwiązania mogą być przesyłane do nauczyciela (w szczególności, gdy są to obszerne zadania opisowe), lub też w przypadku interaktywnych testów, student realizuje samodzielny tok nauki.

Poniżej zostały podane dwa przykłady zadań opisowych i testów:

a) zadanie opisowe $\mathrm{z}$ możliwością zapoznania się $\mathrm{z}$ odpowiedzią sugerowaną przez nauczyciela dostęp do podpowiedzi lub wzorcowych odpowiedzi (przygotowanych przez nauczyciela) może być uwarunkowany, np.: odpowiedzią na pytania pomocnicze (przejście do kolejnego pytania pomocniczego może być uwarunkowane wskazaniem prawidłowego rozwiązania przy pierwszym pytaniu);

b) testy (pytanie testowe i np.: pięć odpowiedzi) - wskazanie nieprawidłowej odpowiedzi powoduje wyświetlenie komunikatu $\mathrm{z}$ podpowiedzią naprowadzającą na prawidłową odpowiedź (każda błędna odpowiedź może być opatrzona innym komentarzem); w przypadku drugiego lub trzeciego błędnego wskazania system sam może wyświetlić poprawną odpowiedź. Po zakończeniu testu student może zapoznać się ze statystyką. Podsumowanie to znakomicie systematyzuje wiedzę, zawiera $\mathrm{w}$ jednej tabeli treść wszystkich zadań, wskazania studenta oraz poprawne odpowiedzi. Dodatkowo system informuje, ile razy student próbował wskazać właściwą odpowiedź. Oprócz tych standardowych zadań i testów możliwe jest wdrożenie wielu innych rodzajów interaktywnych materiałów. Mogą to być studia przypadków do rozwiązywania przez grupę studentów. W tym wypadku nauczyciel zyskuje następne narzędzie do komunikowania się ze studentami: terminarz, w którym rozdziela zadania i rozlicza $\mathrm{z}$ ich wykonania.

Każdemu materiałowi uzupełniającemu tradycyjne studia towarzyszy szereg dodatkowych funkcji. Jedną z podstawowych funkcji charakteryzujących nauczanie przez Internet są wirtualne konsultacje. Na platformie e-sgh.pl odbywa się to przede wszystkim poprzez pokój rozmów - czat. Wirtualne konsultacje powinny odbywać się przynajmniej dwa razy w przerwie pomiędzy 
zjazdami: raz w godzinach pracy, drugi raz wieczorem (tak, aby każdy student zaoczny, pracujący lub nie, miał możliwość skorzystania z konsultacji). Innym, równie ważnym i bardzo dobrze rozwijającym się narzędziem komunikacji jest forum dyskusyjne. Jest ono dostępne dla wszystkich, wyznaczonych uczestników zawiera wypowiedzi studentów i odpowiedzi nauczyciela. W każdej chwili nowy uczestnik może dołączyć się do dyskusji. System został także wyposażony $\mathrm{w}$ możliwość powiadamiania studentów o nowo udostępnianych funkcjach i wykładach poprzez e-mail oraz tablicę aktualności, która jest widoczna zaraz po zalogowaniu się do systemu.

\subsubsection{Ośrodka Edukacji Niestacjonarnej Politechniki Świętokrzyskiej}

Chcąc wzbogacić swoją wiedzę z zagadnień informatycznych, można odwiedzić serwis Ośrodka Edukacji Niestacjonarnej Politechniki Świętokrzyskiej. Oferuje on szereg kursów raczej dla niezaawansowanych entuzjastów informatyki. Wśród oferowanych produktów edukacyjnych można znaleźć: Podstawy Architektury Komputerów, AutoCad 2005, System operacyjny Windows, MS Word, MS Excel, MS Access.

Istnieje również możliwość nauki języka angielskiego za pomocą narzędzi e-learningowych oferowanych przez Ośrodek Edukacji Niestacjonarnej. Nauka odbywa się w zależności od umiejętności słuchacza na trzech poziomach: dla początkujących JA1-KNO, średniozaawansowanych JA2-KNO i zaawansowanych JA3-KNO.

Kurs jest realizowany samodzielnie przez słuchacza $\mathrm{w}$ oparciu o multimedialny interaktywny kurs. Jego realizacja przebiega $\mathrm{w}$ systemie złożonym $\mathrm{z}$ elementów kształcenia na odległość i metody tradycyjnej.

Uczestnik ma swobodny dostęp do tej części materiału, która odpowiada poziomowi jego wiedzy i realizuje go w wybranej przez siebie kolejności, ilości i tempie. Część godzin realizowana jest na cotygodniowych warsztatach. Kurs ma strukturę modułową. Każdy z sześciu modułów danego poziomu dzielony jest na dwie jednostki odpowiadające dwóm spotkaniom. Jednostka obejmuje dwie i pół lekcji według kursu komputerowego. W przeciągu ok. 3,5 miesiąca odbędzie się w sumie 13 warsztatów. Ostatnie, 13-ste spotkanie, przygotowujące do egzaminu, poświęcone będzie powtórzeniu całego materiału $\mathrm{w}$ oparciu o lekcje powtórzeniowe przerabiane przez studentów samodzielnie na bieżąco oraz ćwiczenia zawarte w pakiecie materiałów dodatkowych. Zaliczanie modułów odbywa się na bieżąco na warsztatach i w godzinach konsultacji lektora. Test zaliczeniowy pisany jest na zajęciach, a inne prace kontrolne mogą być wykonane w domu i dostarczone bezpośrednio lub z wykorzystaniem dostępnych mediów, tj. e-mailem, faxem lub pocztą. Warunkiem dopuszczenia do egzaminu jest zaliczenie wszystkich sześciu modułów (OKNO, Ośrodek Edukacji Niestacjonarnej przy Politechnice Świętokrzyskiej).

\subsubsection{Centrum Otwartej Multimedialnej Edukacji Uniwersytetu Warszawskiego}

$>$ Centrum Otwartej Multimedialnej Edukacji jest międzywydziałową jednostką Uniwersytetu Warszawskiego. Jej misją jest niwelowanie barier geograficznych, czasowych czy społecznych w dotarciu do edukacji akademickiej. Dzięki wykorzystaniu nowoczesnych technologii propaguje on edukację, oferując wszystkim zainteresowanym odbycie kursów internetowych. Tematyka kursów jest zróżnicowana i wśród bogatej oferty możemy znaleźć następujące pozycje:

$>$ Survival Polish, Social Change in Poland;

$>$ Ocenianie w edukacji;

$>$ Pedagogika międzykulturowa;

$>$ Szkolenie biblioteczne;

$>$ Psychologia jedzenia;

$>$ Psychologia motywacji;

$>$ Psychologia odchudzania;

> Dyskutowanie $\mathrm{w}$ grupie po angielsku; Pisanie streszczeń w języku angielskim;

$>$ Epigrafika Majów; 
Część kursów jest darmowa a za resztę trzeba zapłacić od 100zł do 700zł. Więcej informacji na temat kursów organizowanych przez Centrum Otwartej Multimedialnej Edukacji można znaleźć odwiedzając serwis internetowy http://www.come.uw.edu.pl.

\subsection{Zagraniczne uczelnie on-line}

Jedną z największych korzyści jaką daje nam edukacja wirtualna jest niezależność od miejsca nauki. Dzięki temu nie ruszając się z domu możemy zdobywać dyplomy renomowanych zagranicznych uczelni takich jak: Oxford University, University of London, California State University, American Capital University, Ellis College of New York Institute of Technology, Hong Kong Cyber University i wielu innych.

\subsubsection{Oxford on-line}

Marzeniem wielu studentów jest zdobycie dyplomu Oxford University. Aby rozpocząć edukację na tej prestiżowej uczelni musimy spełniać kilka warunków. Pierwsze z nich to znajomość języka angielskiego. Wszyscy kandydaci, których język angielski nie jest językiem rodzimym powinni posiadać jeden z poniższych certyfikatów:

$>$ GCSE English Language (ocena C lub wyższa);

$>$ British Council IELTS English Language na poziomie 6.5 punktów (moduł akademicki);

$>$ TOEFL English Language co najmniej 650 punktów;

$>$ Cambridge Certificate of Advanced English (ocena C lub wyższa);

$>$ Inne zaświadczenie znajomości języka angielskiego na poziomie zatwierdzonym przez uczelnię.

Kolejnym kryterium jest posiadanie podstawowych wiadomości z zakresu baz danych oraz arkusza kalkulacyjnego, a także posiadanie dostępu do komputera o następującej minimalnej specyfikacji technicznej:

$>$ Częstotliwość procesora CPU - $400 \mathrm{MHz}$

$>$ Pamięć operacyjna $128 \mathrm{MB}$ of RAM

$>$ System operacyjny Windows 98

$>$ Miejsce wolne na dysku twardym na zainstalowanie oprogramowania 300MB

$>$ Rozdzielczość monitora SVGA display 800 x 600

$>$ Napęd CDROM

$>$ Karta muzyczna

$>$ Głośniki

$>$ Dostęp do Internetu np. przez modem

$>$ Myszka, klawiatura

$>$ Przeglądarka Internetowa w wersji nie starszej niż MS Internet Explorer 5

$>$ Zainstalowane oprogramowanie: Flash 5 Player lub wyższe; Adobe Acrobat 5 viewer (wersja standartowa lub wyższa); Quick Time Player

$>$ Microsoft Office 97

Niestety nauka na zagranicznych uczelniach nie należy do tanich i trzeba liczyć się z wydatkiem na opłaty wpisowe i czesne. W przypadku Oxford University, za dwu letnie studia z Diploma in Computing roczne czesne dla studenta z Unii Europejskiej wynosi 850£, a słuchaczy spoza Unii Europejskiej 2.300£. Studenci muszą liczyć się jeszcze z dodatkowym kosztem w postaci zaliczeniowego zjazdu Summer School. Przewidywany koszt studiów to około $2000 £$ plus opłaty związane z zakwaterowaniem oraz podróżą. Jeżeli przyszły student podoła stawianym mu wymaganiom może ubiegać się o przyjęcie na uczelnie wypełniając formularz znajdujący się na następującej stronie:

http://www.conted.ox.ac.uk/courses/computing/promo/application/application_form.asp

\subsubsection{External Programme University of London}

Bardzo ciekawą propozycję edukacji dla studentów z całego świata posiada University of London. Uruchomiony tam już w 1858 roku External Programme umożliwiał słuchaczom, którzy z różnych względów nie mogli osobiście uczestniczyć w tradycyjnych zajęciach zdobycie dyplomu. Metody nauki przez szereg lat ewoluowały dostosowując się do panujących rozwiązań i trendów technologicznych. Student za pomocą nowoczesnych rozwiązań może zdobyć dyplom licencjata oraz magistra. Ceny wahają się od $1.500 £$ do $2.500 £$ za licencjat i od $7.000 £$ do $10.000 £$ 
za magisterium. Na większości studiów czas nauki można dostosowywać do swojego tępa i może on trwać nawet do 8 lat. Uczelnia posiada bogatą ofertę studiów od Księgowości i Finansów poprzez Biznes i Zarządzanie, Filologie, Socjologię na Prawie kończąc.

Dużą dogodnością ze strony uczelni jest fakt, iż na egzaminy studenci nie muszą przyjeżdżać do Londynu, ponieważ przedmioty można zdawać $w$ terenowych centrach na całym świecie. Więcej informacji na temat uczelni znajduje się $w$ serwisie internetowym pod adresem: http://www.londonexternal.ac.uk/about_us/index.shtml.

\subsubsection{The University of Liverpool}

Kolejną możliwość na otrzymanie dyplomu prestiżowej uczelni zagranicznej daje nam Uniwersytet w Liverpoolu. Swoją działalność on-line prowadzi od 2000 roku, a z jego oferty skorzystało wielu studentów z 90 krajów. Istnieje możliwość uczestniczenia w studiach magisterskich lub MBA z informatyki. Oferta uczelni jest kierowana głównie do osób pracujących na kierowniczych stanowiskach. Ceny za studia wahają się od $12.000 £$ do $14.500 £$ za magisterium, oraz od $14.300 £$ do $14.500 £$ za MBA. Do należności wobec uczelni należy również doliczyć opłatę wpisową $90 £$, koszt uzyskania 180 punktów niezbędnych do przyjęcia oraz książki i członkostwo w bibliotece. Uczelnia umożliwia regulowanie należności jednorazowo, w trzech ratach lub opłacanie pojedynczych modułów. Aby zapisać się na Uniwersytet w Liverpoolu należy wypełnić formularz dostępny na stronie http://www.uol.ohecampus.com/admissions/apply.phtml\#.

\subsubsection{Virtual Global University}

Virtual Global University (VGO) to prywatna organizacja edukacyjna, której założycielami jest 17 profesorów z uczelni niemieckich, austriackich oraz szwajcarskich. VGO specjalizuje się w prowadzeniu studiów dla absolwentów i osób pracujących posiadających wykształcenie wyższe np.: licencjat, inżynier lub magister. VGO wyspecjalizowanych w prowadzeniu zajęć $\mathrm{z}$ tematyki IT oraz zarządzania. Zajęcia na VGU składają się z wykładów online i wykorzystują narzędzia multimedialne. Studenci mogą liczyć na indywidualną pomoc ze strony profesorów i asystentów poprzez kontakt e-mail, chat, forum lub hotline. Uniwersytet wystawia certyfikaty ukończenia poszczególnych kursów i ponadto oferuje uzupełniające studia magisterskie $\mathrm{z}$ dyplomem "International Master of Business Informatics“ (MBI). Tytuł ten nadawany jest przy współpracy z Uniwersytetem Europejskim Viadrina w Niemczech.

IVGU posiada bardzo interesującą ofertę studiów MBI. International Master of Business Informatics (MBI) to dwuletni kierunek, który rozpoczyna się w październiku każdego roku. Podczas trzech pierwszych semestrów student zobowiązany jest opanować materiał i zdać pomyślnie wszystkie egzaminy. Czwarty semestr przeznaczony jest na napisanie pracy magisterskiej oraz odbycie praktyki lub wzięcie udziału w projekcie. Studiować można zarówno w trybie dziennym jak i zaocznym. Kurs MBI oparty jest na technologiach multimedialnych takich jak: video, audio streaming, hypermedia (skojarzone strony), synchronizowane prezentacje i podręczniki z materiałami online. Kierunek MBI porusza najistotniejsze zagadnienia technologii informacyjnych począwszy od informatyki stosowanej, sieci komputerowych i Internetu poprzez tworzenie stron internetowych, zarządzanie bazami danych i kończąc na programowaniu oraz wdrażaniu systemów informacyjnych. Omawiana jest również tematyka związana z zarządzaniem, gdzie nacisk kładzie się na e-commerce oraz e-business, zarządzanie systemami informacyjnymi, modelowanie procesów biznesowych i enterprise resource planning. Dodatkowo istnieje możliwość wyboru przedmiotów z grupy wolnej konfiguracji. Mogą to być przykładowo: business intelligence, bezpieczeństwo systemów, zarządzanie wiedzą lub przemysłowe systemy informacyjne. MBI to wspólny projekt Virtual Global Uniwersity i niemieckiego Uniwersytetu Europejskiego Viadrina we Frankfurcie nad Odrą. Podczas gdy VGU zajmuje się dydaktczną częścią programu, uniwersystet Viadrina zapewnia kontrolę i utrzymanie odpowiedniego poziomu kształcenia. Tytuł „Master” jest oficjalnie zatwierdzony przez rząd i akredytowany przez FIBAA (Foundation for International Business Administration Accreditation) (VGU - Virtual Global University, http://www.vg-u.de/vgu-polish.html). 


\section{$5 \quad$ Zalety i wady nauki na odległość}

Z badań prowadzonych przez różne placówki oraz organizacje wynika, że e-learning jest równie efektywny jak nauczanie tradycyjne. W e-learningu często rolę tradycyjnego nauczyciela zajmuje „wirtualny”, który nie ma bezpośredniego kontaktu z uczniem. Dzięki temu, nie jest konieczne przeprowadzanie zajęć $\mathrm{w}$ określonych porach dnia (chyba, że korzystamy $\mathrm{z}$ wirtualnej klasy). Uczeń może przyswajać wiedzę $\mathrm{w}$ dowolnym momencie. Osoby uczące się mogą zatem dopasować czas kursu do własnego tempa nauki, choć zmuszone są przez to do większego wysiłku i dłuższej pracy. $\mathrm{W}$ tradycyjnym nauczaniu natomiast efektywność uczenia się $\mathrm{w}$ tempie narzuconym przez prowadzącego w miarę upływu czasu spada.

Użytkownicy online muszą sami wybrać odpowiednie dla nich materiały w Internecie. Podczas nauki uczeń nie może informować na bieżąco nauczyciela o swoich problemach - musi oczekiwać na kontakt. W klasie tradycyjnej natomiast, nauczyciel może zwrócić uwagę uczniom zanim wystąpią problemy, korygując ich działania, - co nie jest możliwe podczas kształcenia na odległość. Uczniowie online muszą wykazać się też większą samodzielnością w rozwiązywaniu problemów i zdobywać wiedzę w sposób aktywny, a nie czekać na nią.

W jakich sytuacjach możemy, więc powiedzieć, że e-learning jest lepszy niż nauczanie tradycyjne? Zależy to od obszaru stosowania. Najodpowiedniejsze - ze względu na poważną redukcję kosztów wydają się szkolenia mające na celu podniesienie kwalifikacji oraz wiedzy pracowników. Chcąc tradycyjnie przeprowadzić takie szkolenie, musimy brać pod uwagę związane z tym:

$>$ trudności w zgromadzeniu wielu słuchaczy w jednym miejscu i czasie;

$>$ koszty wynajęcia wykładowcy;

$>$ koszty przejazdów i zakwaterowania uczestników szkolenia;

trudności w przystosowaniu tempa nauki do średniego poziomu grupy;

$>$ trudności w utrwaleniu wiedzy;

$>$ niedostatek indywidualnego kontaktu z wykładowcą.

Zyskujemy natomiast $\mathrm{m}$. in. na podwyższeniu poziomu integracji grupy.

Przeprowadzając takie samo szkolenie metodą e-learningu, ograniczamy prawie wszystkie koszty (nie licząc kosztów zakupu sprzętu komputerowego, jego oprogramowania, kosztów dostępu do sieci, itp.), ponieważ:

$>$ materiały szkoleniowe udostępniane są w postaci elektronicznej (odpadają więc koszty druku, pojawia się możliwość powielania),

$>$ można dokonać symulacji (za pomocą odpowiedniego oprogramowania) warunków fizycznych potrzebnych do prowadzenia szkolenia oraz sytuacji niemożliwych do uzyskania w klasie, można przedstawić wiele scenariuszy, a potem je wielokrotnie badać zgodnie z potrzebami pojawiającymi się podczas nauki,

$>$ pracownik może szkolić się w czasie mniejszego obciążenia pracą.

Firmy zajmujące się profesjonalnie e-learningiem wskazują jeszcze na inne jego wady i zalety. Oto niektóre $\mathrm{z}$ tych wad:

$>$ duży koszt profesjonalnych platform, (zakup platformy, sprzętu);

$>$ brak bezpośredniego kontaktu z prowadzącym;

$>$ konieczność posiadania silnej motywacji oraz chęci do uczenia się;

$>$ konieczność posiadania Internetu lub dostępu do niego w postaci szybkiego łącza;

$>$ brak integracji następującej podczas szkoleń tradycyjnych;

$>$ problemy ze sprawdzeniem efektywności;

Podkreślają jednocześnie wiele zalet e-learningu;

$>$ zarządzanie procesem nauczania;

$>$ szybkość przekazu wiedzy i umiejętności;

> bieżąca kontrola postępów;

$>$ indywidualizacja procesu nauczania;

$>$ multimedialne formy przekazu; 


\section{Zakończenie}

E-learning jest to metoda nauki, która dzięki szeroko rozwiniętej globalizacji oraz dynamicznemu wzrostowi technologicznemu znajduje duże zainteresowanie po stronach ośrodków edukacyjnych jak i samych odbiorców - studentów, pracowników firm, itd. Korzyści płynące z tej metody są obopólne. Słuchacz może korzystać z udostępnionych materiałów z każdego miejsca przez 24 godziny na dobę. W każdym momencie może zadać prowadzącemu pytania, odsłuchać wykłady, zapoznać się z multimedialnymi nagraniami audio-video, a często za pomocą Internetu zdawać egzamin. Dla uczelni ta metoda jest dużo tańsza niż prowadzenie tradycyjnych zajęć. Ze względu na fakt, iż coraz więcej osób podejmuje naukę na wyższych uczelniach, ośrodek akademicki nie musi budować i wyposażać dodatkowych pomieszczeń, zaoszczędza również na zatrudnianiu dodatkowej liczby wykładowców. Wykłady $\mathrm{z}$ danego przedmiotu są opracowywane zbiorczo, przez co wykładowca nie musi wiele razy powtarzać materiału z tego samego zakresu.

Edukacja na odległość, chociaż nie jest w stanie zastąpić w stu procentach tradycyjnej metody nauczania, stanowi jednak kierunek, w którym edukacja będzie podążała w XXI wieku. Zbyt często jednak metodycy i twórcy kursów zdalnych są nadto zainspirowani technologią, aby zauważyć potrzeby uczących się, rozważyć jakość dostępu do interaktywnych systemów i funkcji mediów w procesie nauczania, a także przeanalizować nową rolę nauczyciela.

Podsumowując, należy odwołać się do słów L. Sherry (Issuses In Distance Learning), która podkreśla, iż najważniejszymi elementami metodyki na odległość są:

$>$ systematyczność rozwoju metodyki (efektywna metodyka musi brać pod uwagę nie tylko cele nauczania, potrzeby i charakterystykę nauczycieli i uczniów, ale także wymagania, co do treści i możliwości technicznych);

$>$ interaktywność (gdyż jakość procesów edukacyjnych zależy komunikacji);

$>$ aktywność uczniów, wizualność przekazu (która przede wszystkim motywuje do nauki);

$>$ efektywność komunikacji. 


\section{Bibliografia}

Horton, W., Horton, K. 2003. E-learning Tools and Technologies. Indianapolis: Wiley Publishing, Inc. Kłosowski, T. 2003. Porównanie systemów edukacji zdalnej. Wirtualna Edukacja Nr 13. (http://ttf.ieee.org/we/t013.html - 30 listopad 2006).

Sherry, L. 2005. Issues in Distance Learning. (http://www.puw.pl/ - 30 listopad 2006).

Mielcarek, P., Parczewski, M., Madejski, L. 2004. E-learning - analiza celów i możliwości ich realizacja na podstawie istniejących specyfikacji I standardów. [w]: E. Niedzielska, H. Dudycz, M. Dyczkowski (red.). Nowoczesne Technologie Informacyjne w Zarządzaniu. Prace Naukowe Akademii Ekonomicznej im. Oskara Langego. Wrocław: Oficyna Akademii Ekonomicznej, vol. 1044, s. 548-556 (http://madeyski.e-informatyka.pl/download/20.pdf) .

Rokicki, B., Świętochowski, P., Romaniuk, R. 2004. Model systemu Bazy Wykładów dla Ośrodka Kształcenia. (http://www.ise.pw.edu.pl/ rrom/papers/okno.pdf - 30 listopad 2006) .

Romaniuk, R. 2001. Optyczny Internet Terabitowy. Warszawa: Komitet Elektroniki i Telekomunikacji PAN. Schank, R. 2003. Designing Word-class e-Learning. Chicago: Mc Graw Hill.

Siemieniecki, B., Lewandowski, W. 2004. Internet w szkole. Torun: Multimedialna Biblioteka Pedagogiczna. Waller, V. 2003. On-line learning - Is it just hype?. Brighton: The Traning Foundation.

\section{Źródła internetowe}

Ośrodek Kształcenia na odległość przy Politechnice Warszawskiej (http://pamctr.uni.lodz.pl - 30 listopad 2006). Polsko Amerykańskie Centrum Zarządzania (PAM Center). (http://pamctr.uni.lodz.pl/ - 30 listopad 2006).

VGU - Virtual Global University (http://www.vg-u.de/vgu-polish.html - 30 listopad 2006). 